\title{
An Economic Analysis of Onion Cultivation in Giridih District of Jharkhand
}

\author{
Punit Kumar Agarwal ${ }^{1 *}$ and Manish Kumar ${ }^{2}$ \\ ${ }^{1}$ Department of Agricultural Economics and Statistics, Kulbhaskar Asharam PG College, Allahabad-211002, UP, India \\ ${ }^{2}$ Student of Ramakrishna Mission Vivekananda University, Ranchi-834008, India \\ *Corresponding author: punitagriculture@gmail.com
}

\begin{abstract}
The study was carried out in Giridih district of Jharkhand with the objectives to work out the cost and return structure of onion cultivation and to identify the major constraints confronted by the farmers in onion cultivation. For the selection of respondent's multistage sampling design was employed. Primary data was collected from sample of 120 onion growing farmers. The data so collected pertained to the Rabi season of the agricultural year 2016-17. The study concluded that, the average cost of cultivation of onion in Dhanwar block was ₹ 57687.95 per acreage which was higher than ₹ 50374.3 in case of Birni. The total variable cost per acre in Dhanwar was ₹ 45325.16 and in Birni it was ₹ 41691.40. The output per acre in Dhanwar was 65.52 quintal and in Birni it was 46.00 quintal/acre. The return per rupee investment was around ₹ 1.71 and ₹ 1.34 over variable and total cost respectively in case of Dhanwar block. In Birni block it was ₹ 1.65 over variable cost and ₹ 1.37 over fixed cost. The major problems in cultivation of onion were lack of water for irrigation, high cost of seeds, pest and diseases, awareness on optimum use of fertilizers, high cost of labour etc.
\end{abstract}

Keywords: Profitability, B: C ratio, Cost of Cultivation, Optimum output, Onion cultivation

India's economy predominantly depends upon agriculture and its allied sectors. The total cropped area is 194 million hectare on which 58 per cent livelihood is depending today. Indian agriculture is mainly characterized by, rainfall dependent and low productivity of food grains and vegetables. India is blessed with diverse agro-climatic zones with distinct seasons. That's why it is possible to grow wide range of vegetables in India. Vegetables are the vital component in diets of people in this world. As per the reports of Horticulture Statistic Division (2014-2015) in India, vegetables are grown in an area of about 9.57 million hectares and productivity of the same is $17.7 \mathrm{mt} /$ hectare. These vegetables are consumed in the country as well as exported to other nations also. Among all the vegetables onion has the largest acreage which is around 1.18 million hectares. This crop is not only used extensively within the country but also highest foreign exchange earner among horticultural crops. Onion accounts for 67 per cent of total foreign exchange among fresh vegetable. China is the largest producer of onion. As per the records of Directorate of Onion and Garlic Research (2012), the total area (lakh ha), production (lakh ton) and productivity (tons/ ha) of onion in china was 10.25, 226 and 22.05, respectively. Whereas, in same year, the area (lakh ha), production (lakh tons) and productivity (tons/ ha) of onion in India was 9.59, 163.09 and 17.01, respectively. The state Jharkhand comes under Agro-Climatic Zone VII (Eastern Plateau and hill region). Agriculture and allied activities are the main stay for 80 per cent of rural population residing in 32620 villages. Vegetables are the good source of income for the farmers of Jharkhand. They get quite better price from vegetables. Onion is cultivated in Jharkhand on small to a large basis. The productivity of onion in Jharkhand is 19.69 (ton/ ha), area ('000ha) is 16.39 and production ('000MT) is 322.73. Onion is an important crop of the farmers of Jharkhand. This crop will give a good return to farmers, if it is cultivated and managed properly. 
In recent years, a wide fluctuation in onion is observed throughout the country, but the demand remained unaltered. Instead of such economic benefits of onion, there are also some constraints associated with its production. As agriculture in Jharkhand is totally dependent on rainfall, uneven distribution of rainfall decreases the productivity of onion. In Jharkhand most of the farmers are small and marginal and thus they have very small land holdings. This prevents them to use latest production technologies and implements, hybrid or high yielding varieties of seeds, irrigation systems and disease and pest control measures, labours in the production/cultivation process. Keeping with the view of above issues, an attempt was made to study the economics of onion cultivation by Jharkhand farmers.

\section{Specific Objectives}

1. To work out the cost and return structure of onion cultivation.

2. To identify the major constraints confronted by the farmers in onion cultivation.

\section{RESEARCH METHODOLOGY}

The study is based on the input and output data collected from the respondents of two blocks viz. Birni and Dhanwar of Giridih district. For selection of respondent's multistage sampling design was employed. In this procedure, at first stage Giridih district was selected purposively. From Giridih district Birni block and Dhanwar block followed onion cultivation were purposively selected due to suitable areas for onion crop and well known to researcher. Then on the third stage, a list of all the villages growing onion, falling under Birni and Dhanwar block was prepared. Then from this list, five villages from each block were selected randomly. From Birni block the villages selected were Kalyanpur, Kubri, bishunpura, Belna and Garaidih. From Dhanwar block the villages selected were Parsan, Khizarsota, Rupnadih, Kailadhab and Purrekh. From each of selected village, a list of onion growers was prepared in ascending order according to the size of their holding under onion crop in their total cropped area. In the final stage, 12 farmers from each village was selected, who was having more area under onion cultivation. Thus, the total sample size was 120 . The data so collected pertained to the Rabi season of the agricultural year 2016-17.

\section{Analytical Procedure}

\section{Estimation of Costs and Returns}

The farm management, cost concept approach is widely used in India for evaluating crop profitability in production. The cost concepts in brief, are Cost $\mathrm{A} 1, \mathrm{~A} 2, \mathrm{~B} 1, \mathrm{~B} 2, \mathrm{C} 1, \mathrm{C} 2$, and cost $\mathrm{C} 3$.

COST A1: This gives the total cash expenses incurred by the owner or operator. It includes the following terms of costs.

1. Value of hired human labour.

2. Value of bullock labour.

3. Value of machinery charges

4. Value of fertilizers and manures.

5. Value of seeds.

6. Value of insecticides, pesticides and weedicide.

7. Irrigation charges.

8. Depreciation on farm implements

9. Interest on working capital.

10. Land revenue paid to government.

COST A2 = Cost A1+ Rent paid for leased in land, if any.

COST B1 = Cost A1 + Interest on value of owned fixed capital assets.

COST B2 = Cost B1 + Rental value of owned land less land revenue

COST C1 = Cost B1 + Imputed value of family labour.

COST C2 = Cost B2 + Imputed value of family labour.

COST C $3=$ Cost C $2+10 \%$ of Cost C 2 on account of managerial functions performed by the farmer.

In the present study, the rent paid for leased in land was zero, as none of the sample farmers took land on lease basis. Hence, cost A1 and cost A2 are similar.

\section{Rates of Returns over Different Cost Concepts}

Gross Income: Yield of main product (in qt./kg) × their prices $(₹)$ 
Net Income: Gross Income - Cost C.

Farm Business Income: Gross Income - Cost A2

Farm Investment Income: Farm business incomewages of family labour

Family Labour Income: Gross Income - Cost B

Cost of production: The cost of production was worked by the following formula:

Cost of production/qt $=$

$\frac{\text { Cost of cultivation/ha }}{\text { Quantity of main product/ha }}$

To identify the major constraints confronted by the farmers in onion cultivation.

For achieving this objective, Garret's Ranking Technique was used.

Garret's Ranking Technique (Garret and Woodworth, 1969)

$$
\text { Percent Position }=100(R i j-0.50) / N i j
$$

Where $R i j$ is the rank given given for $i^{\text {th }}$ item by the $J^{\text {th }}$ individual.

$N i j$ is the number of items ranked by the $J^{\text {th }}$ individual.

The percent position of each rank was converted into scores using Garrett table. For each constraint, scores of individual respondents were added together and were divided by the total number of respondents for whom scores were added. Thus, the mean score for each constraint was ranked by arranging them in descending order.

\section{RESULTS AND DISCUSSION}

The profitability of onion cultivation in study area has been analyzed by computing per acre costs and returns. Table 1 depicts the pattern of input used for onion cultivation in both the blocks.

The overall cost of cultivation of onion per acre in Dhanwar was found to be ₹ 57687.95. Out of which total variable cost was ₹ 45325.16 (78.56 per cent) rest covered by fixed cost. Human labour value had the highest percent in total variable cost. This constituted about 38.81 per cent of total variable cost. The next major expenditure in total variable cost was on fertilizers and manures (23.50 per cent), followed by bullock labour (18.8 per cent) and seed
(10.48 per cent). The total fixed cost was worked out to be ₹ 7118.43. In Birni Block, the overall cost of cultivation per acre was calculated to be ₹ 50374.30. Out of which the total variable cost was ₹ 41691.40. In variable cost major share covered by human labour (39.2 per cent) followed by fertilizers and manures (15.76 per cent), bullock labour (14.65 per cent) and seed (12.87 per cent). The total fixed cost was ₹ 4103.42 .

Table 1: Per acre Input use pattern of Onion Cultivation

\begin{tabular}{|c|c|c|c|c|c|}
\hline \multirow{2}{*}{$\begin{array}{l}\text { Sl. } \\
\text { No. }\end{array}$} & \multirow[b]{2}{*}{ Pariculars } & \multicolumn{2}{|c|}{ Dhanwar } & \multicolumn{2}{|c|}{ Birni } \\
\hline & & $\begin{array}{l}\text { Expendi- } \\
\text { ture }\end{array}$ & $\begin{array}{c}\text { Percent- } \\
\text { age }\end{array}$ & $\begin{array}{l}\text { Expendi- } \\
\text { ture }\end{array}$ & $\begin{array}{c}\text { Per- } \\
\text { centage }\end{array}$ \\
\hline \multicolumn{6}{|c|}{ Variable Cost } \\
\hline 1 & Seed & 4750.57 & 8.23 & 5368.40 & 10.66 \\
\hline 2 & \multicolumn{5}{|c|}{ Fertilizers and Manures } \\
\hline A & Urea & 391.63 & 0.68 & 326.92 & 0.65 \\
\hline B & DAP & 1349.85 & 2.34 & 1171.84 & 2.32 \\
\hline $\mathrm{C}$ & Potash & 555.84 & 0.96 & 372.00 & 0.74 \\
\hline $\mathrm{D}$ & Sulphate & 222.90 & 0.39 & 280.35 & 0.55 \\
\hline E & Compost & 7895.67 & 13.69 & 4420.91 & 8.77 \\
\hline $\mathrm{F}$ & Phosphate & 234.07 & 0.40 & 0.00 & 0.00 \\
\hline & Sub total & 10649.99 & 18.46 & 6572.02 & 13.04 \\
\hline 3 & $\begin{array}{l}\text { Plant } \\
\text { protection } \\
\text { chemicals }\end{array}$ & 139.28 & 0.24 & 1378.67 & 2.74 \\
\hline 4 & Irrigation & 1036.66 & 1.80 & 1033.33 & 2.05 \\
\hline 5 & \multicolumn{5}{|c|}{ Labour } \\
\hline A & $\begin{array}{l}\text { Family } \\
\text { labour }\end{array}$ & 17166.99 & 29.75 & 15460.52 & 30.69 \\
\hline B & Hired labour & 424.57 & 0.73 & 913.35 & 1.81 \\
\hline & Sub total & 17591.56 & 30.49 & 16373.87 & 32.50 \\
\hline 6 & $\begin{array}{l}\text { Bullock } \\
\text { labour }\end{array}$ & 8538.43 & 14.80 & 6111.90 & 12.13 \\
\hline 7 & $\begin{array}{l}\text { Machine } \\
\text { labour }\end{array}$ & 1729.92 & 3.00 & 4035.71 & 8.02 \\
\hline 8 & $\begin{array}{c}\text { Interest on } \\
\text { working } \\
\text { capital }\end{array}$ & 888.73 & 1.54 & 817.47 & 1.61 \\
\hline & $\begin{array}{c}\text { Total } \\
\text { variable cost }\end{array}$ & 45325.16 & 78.56 & 41691.40 & 82.76 \\
\hline \multicolumn{6}{|c|}{ Fixed Cost } \\
\hline 1 & $\begin{array}{l}\text { Land } \\
\text { revenue }\end{array}$ & 11.55 & 0.02 & 12.73 & 0.02 \\
\hline 2 & $\begin{array}{l}\text { Rental value } \\
\text { of own land }\end{array}$ & 5758.33 & 9.98 & 3116.67 & 6.19 \\
\hline 3 & Depreciation & 1074.76 & 1.86 & 816.20 & 1.62 \\
\hline 4 & $\begin{array}{l}\text { Interest on } \\
\text { fixed capital }\end{array}$ & 273.78 & 0.47 & 157.82 & 0.31 \\
\hline
\end{tabular}




\begin{tabular}{ccccc} 
Total fixed & $\mathbf{7 1 1 8 . 4 3}$ & $\mathbf{1 2 . 3 3}$ & $\mathbf{4 1 0 3 . 4 2}$ & $\mathbf{8 . 1 4}$ \\
cost & & & & \\
\hline $\begin{array}{c}\text { Managerial } \\
\text { cost }\end{array}$ & 5244.36 & 9.09 & 4579.48 & 9.09 \\
$\begin{array}{c}\text { Total cost of } \\
\text { cultivation }\end{array}$ & 57687.95 & 100.00 & 50374.30 & 100.00 \\
\hline
\end{tabular}

The return structure of onion cultivation for both blocks have given in the Table 2 .

Table 2: Comparison of return structure of onion cultivation in both Blocks

\begin{tabular}{|c|c|c|}
\hline Particulars & Dhanwar & Birni \\
\hline \multicolumn{3}{|c|}{ Income measures (₹/acre) } \\
\hline Gross income & 77541.43 & 69013.99 \\
\hline Net income & 19853.47 & 18639.69 \\
\hline $\begin{array}{l}\text { Farm business } \\
\text { income }\end{array}$ & 48296.94 & 41954.18 \\
\hline Farm labour income & 42264.82 & 38679.69 \\
\hline $\begin{array}{c}\text { Farm investment } \\
\text { income }\end{array}$ & 31129.95 & 26493.66 \\
\hline \multicolumn{3}{|c|}{ Cost of production } \\
\hline Output (Q) & 65.52 & 46 \\
\hline $\begin{array}{c}\text { Cost of production } \\
(₹ / Q)\end{array}$ & 880.38 & 1094.87 \\
\hline \multicolumn{3}{|c|}{$\mathrm{B}: \mathrm{C}$ ratio } \\
\hline $\begin{array}{l}\mathrm{B}: \mathrm{C} \text { ratio on } \\
\text { variable cost }\end{array}$ & 1.71 & 1.65 \\
\hline $\begin{array}{l}\mathrm{B}: \mathrm{C} \text { ratio on total } \\
\text { cost }\end{array}$ & 1.34 & 1.37 \\
\hline
\end{tabular}

The gross income (₹/Acre) for the farmers of Dhanwar was found to be ₹ 77541.43 and for Birni, it was ₹ 69013.99. Net income of the farmers were almost same for boths blocks with very few differences. This little difference in net income was mainly attributed by the high cost of cultivation in Dhanwar i.e. ₹ 57687.95. The other three returns structure namely Farm Business Income, Farm Investment Income and farm Labour Income were also more in Dhanwar than Birni. Because of the comparatively high cost of cultivation of onion in Dhanwar, the production obtained in lands of Dhanwar was more than Birni block. Cost of production, which is the ratio of total cost and output, was lowest in Dhanwar which was ₹ 880.38 per quintal, mainly due to higher output level. In Birni, the cost of production observed from analysis ₹ 1094.87 per quintal. The low cost of production in Dhanwar was due to high level of output. Benefit Cost Ratio shows the income received against per rupees investment. The return per rupee investment was around ₹ 1.71 and ₹ 1.34 over variable and total cost respectively in case of Dhanwar block. In Birni block the B: C ratio estimated over variable cost was $₹ 1.65$ and over total cost was ₹ 1.37. The output per acre in Dhanwar was 65.52 quintal which is much higher than Birni where output per acre was 46 quintal.

The farmers were asked to list priority wise six major constraints they were facing in onion cultivation. All data were sorted, screened and ranks were allotted according to Garret's method. It was clear from the table that first rank was assigned to the high cost of quality seeds. The second most severe problem observed in Dhanwar was scarcity of water followed by high cost of fertilizers, high cost of labour and machinery, disease and weed infestation and lack of awareness on agricultural practices. The branded seeds were more expensive than local seeds, but these seeds gave more output than local seeds. As in summer season, most of the framers were not able to irrigate their cultivable land and thus, the land remained fallow which affects the economy of farmers. Weed, pest and disease infestation were less in the onion fields because of the good management practices.

Table 3: Problems faced by the Respondents in onion cultivation

\begin{tabular}{cccccc}
\hline S1. & Problems & $\begin{array}{c}\text { Percent } \\
\text { position }\end{array}$ & $\begin{array}{c}\text { Garret } \\
\text { value }\end{array}$ & Mean & Rank \\
1 & $\begin{array}{c}\text { Disease, pest and } \\
\text { weed infestation }\end{array}$ & 8.3 & 77 & 36.55 & V \\
2 & Lack of awareness & 25.0 & 63 & 39.68 & VI \\
& $\begin{array}{c}\text { on agricultural } \\
\text { practices }\end{array}$ \\
3 & $\begin{array}{c}\text { High cost of } \\
\text { fertilizers }\end{array}$ & 41.6 & 54 & 48.02 & III \\
4 & $\begin{array}{c}\text { Scarcity of water for } \\
\text { irrigation }\end{array}$ & 58.3 & 46 & 61.63 & II \\
5 & $\begin{array}{c}\text { High cost of quality } \\
\text { seeds }\end{array}$ & 75.0 & 37 & 64.72 & I \\
6 & $\begin{array}{c}\text { High cost of labour } \\
\text { and machinery }\end{array}$ & 91.67 & 23 & 49.40 & IV \\
\hline
\end{tabular}

\section{CONCLUSION}

The core message of this paper is to construct a economic structure of onion cultivation and identification of major constraints of onion cultivation. To investigate this, the present study 
has used cost concept and garrett ranking tool. The average cost of production per acre was calculated to be ₹ 57687.95 for Dhanwar which was higher than Birni ₹ 50374.30. In both the blocks highest cost incurred on total human labour, which was about 30.49 per cent in Dhanwar and 32.5 per cent in Birni due more family labours were involved in the process of onion cultivation followed by fertilizer and manures. The major constraint encountered by respondents in study areas were the high cost of quality seed, lack of irrigation facilities, fertilizer cost, cost of labour, disease and pest infection and awareness level of respondents. The onion in important commercial crop in Jharkhand, therefore, its cultivation may be increased. Yet the growers are confronted with many problems due to which per hectare yield is declining. A large portion of respondents didn't have soil health card and they even did not know how to get it. Government and extension agencies should ensure the proper distribution of soil health card and create awareness on how to use, how much to use and when to use the fertilizers. A major issue reported in both blocks was pest, weed and disease infestation in several crops. So awareness should be created among farmers for disease, pest and weed infestation and their management. For this, cost effective and organic pesticides should be made popular in the villages via large scale demonstration in agricultural fairs and awareness campaign.

\section{REFERENCES}

Agarwal, P.K. and Kumar, A. 2017. A socioeconomic study on pros and cons of SRI method of paddy cultivationin Ormanjhi block of Ranchi district, Jharkhand, India, Indian Journal of Agric. Research, 51(1): 74-77.

Agricultural Statistics at a glance, Department of Agriculture and Cooperation, Ministry of Agriculture, Government of India, 2013 available at http://www.dacnet.nic.in

Agarwal, P.K. and Kumar, A. 2016. Economic appraisal of SRI and traditional method of paddy cultivation: A comparative study, B.Sc (ARTD) Thesis, Ramkrishna Mission Vivekananda University, Ranchi, Jharkhand.

Baloch, R.A. 2014. Economic Analysis of Onion (Allium cepa L.) Production and Marketing in District Awaran, Balochistan, Journal of Economics and Sustainable Development, 5(24): 192-205.

Garret, H.E. and Woodworth, R.S. 1969. Statistics in Psychology and Education. Vakils, Feffer and Simons Pvt. Ltd., Bombay, pp. 329.

https://en.wikipedia.org/wiki/List_of_largest_producing_ countries_of_agricultural_commodities

http://www.apeda.gov.in/apedawebsite/six_head_product/ FFV.htm 
